\title{
New Trends in Paracoccidioidomycosis Epidemiology
}

\author{
Roberto Martinez \\ Division of Infectious Diseases, Department of Internal Medicine, Ribeirão Preto Medical School, \\ Universidade de São Paulo, Sao Paulo 14049-900, Brazil; rmartine@fmrp.usp.br; Tel.: +55-16-3602-2468 \\ Academic Editors: Arnaldo Lopes Colombo and Flavio Queiroz-Telles \\ Received: 29 November 2016; Accepted: 28 December 2016; Published: 3 January 2017
}

\begin{abstract}
Paracoccidioidomycosis is a systemic fungal disease occurring in Latin America and more prevalent in South America. The disease is caused by the dimorphic fungus Paracoccidioides spp. whose major hosts are humans and armadillos. The fungus grows in soil and its infection is associated with exposure to the rural environment and to agricultural activities, with a higher risk in coffee and tobacco plantations. Population studies assessing the reactivity to Paracoccidioides spp. antigens by intradermal reaction or serological tests have detected previous subclinical infections in a significant proportion of healthy individuals living in various endemic countries. Paracoccidioidomycosis-disease is manifested by a small minority of infected individuals. The risk of developing the disease and its type of clinical form are related to the personal and life style characteristics of infected individuals, including genetic background, age, sex, ethnicity, smoking habit, alcohol drinking, and eventual cellular immunosuppression. Brazil, Colombia, Venezuela, Argentina, and Ecuador have endemic areas that had already been defined in the 20th century. The incidence of paracoccidioidomycosis can be altered by climate phenomena and mainly by human migration and occupation of poorly explored territories. In Brazil, the endemy tends to expand towards the North and Center-West around the Amazon Region.
\end{abstract}

Keywords: paracoccidioidomycosis; Paracoccidioides brasiliensis; Paracoccidioides lutzii; epidemiology

\section{Introduction}

Paracoccidioidomycosis is an endemic fungal infection occurring on the American continent from $23^{\circ} \mathrm{N}$ to $23^{\circ} \mathrm{S}$, although with higher prevalence in South America. The infection was first described in 1908 by Adolpho Lutz, who also isolated the microorganism causing the disease from material obtained from oral patient lesions [1]. For a long period of time the thermodimorphic fungus Paracoccidioides brasiliensis, an Ascomycota of the family Ajellomycetaceae, order Onygenales, was recognized as the only agent inducing the mycosis. Genotypic studies revealed variations of $P$. brasiliensis, which was assigned to the cryptic species PS1 (more common and isolated from different regions of South America), PS2 (isolates from Brazil and Venezuela), PS3 (isolates from Colombia), and PS4 (apparently limited to Venezuela) [2]. P. lutzii, a new species of the genus Paracoccidioides, was also identified by means of multilocus sequencing studies [2]. The geographic distribution of P. lutzii is more centered on the Center-West of Brazil, a region inhabited by many patients from whom the microorganism was isolated [3]. Data about pathogenicity or clinical manifestations are relatively unknown when compared to P. brasiliensis. Practically all information about the eco-epidemiology, infection, and disease concerning to Paracoccidioides spp. has been obtained in studies that did not distinguish between the species involved.

Paracoccidioides spp. grows saprophytically in the soil of the American continent but has been seldom isolated from nature, thus preventing the identification of the exact location and of the microniche characteristics of this fungus [4]. P. brasiliensis and P. lutzii have been recently detected by molecular methods in different soil samples from three distinct locations in Brazil [3]. The development of Paracoccidioides spp. in the natural environment, supposedly in its mycelial form, has been associated 
with humid regions, medium to high pluviosity, mild temperatures, and the presence of rivers and forests [5]. More recent studies have reported that Paracoccidioides spp. infection and disease also occur in areas of agricultural crops [6,7] and that armadillos infected with the fungus live in territories with sandy and acidic soil, disturbed natural vegetation, and the presence of rivers [8].

The human species and nine-banded armadillos are the main accidental hosts of Paracoccidioides spp. which can be infected in the rural or periurban environment $[8,9]$. In the rural environment, conidia apparently enter through the respiratory route and reach the lungs, where the infection is usually controlled by the immune cellular response, but may leave behind cicatricial focal points with latent yeast cells. The infection is asymptomatic or manifests clinically with nonspecific symptoms and only a very small percentage of infected individuals progress to the disease [10]. There are no reports of epidemic outbreaks of paracoccidioidomycosis or transmission of Paracoccidioides spp. between individuals.

Paracoccidioidomycosis-disease manifests in two major clinical forms which are distinguished on the basis of demographic and clinical aspects and of the immunological response of the patients [11]. The acute/subacute ("juvenile") form predominantly occurs in children and young adults who have a Th2 type cell immune response which is inadequate to control the fungal infection. The disease develops a few weeks or months after exposure to Paracoccidioides spp., permitting the identification of areas of acquisition of this fungal infection. The most common clinical manifestation in this form of the disease is generalized or intra-abdominal lymphadenomegaly frequently accompanied by lesions of the skin, the oral and intestinal mucosa and the bone, and hepatosplenomegaly. In contrast, the chronic ("adult") form of paracoccidioidomycosis which affects about $80 \%$ to $95 \%$ of cases, usually occurs after 30 years of age and is limited to lesions in the lungs and upper airways and commonly on the oral mucosa and on the skin adjacent to the mouth and nose. Some patients have lesions due to dissemination of the fungus to the adrenals and brain. The period of incubation in the chronic form of the mycosis is uncertain, but the disease is considered to be likely to occur many years after exposure to Paracoccidioides spp.

The present review deals with the epidemiological aspects of paracoccidioidomycosis-disease related both to its acquisition and outcome. The results of studies about the infection of human and animal populations that do not show illness are also presented in order to show the extension and degree of endemicity of the geographic areas occupied by Paracoccidioides spp. The bases of the epidemiology of paracoccidioidomycosis were already known by the mid-twentieth century [1]. However, epidemiological modifications have been observed over the last three decades and have been mainly related to changes of interaction between the human species and the natural environment.

\section{Prevalence, Incidence, Lethality, and Mortality}

In view of the lack of continued recordings of paracoccidioidomycosis cases, the prevalence of this mycosis has been estimated on the basis of reported case series and, in Brazil, also based on hospitalization and mortality data [11-37] (Table 1). Several thousand cases are presumed to be diagnosed each year in the vast territory where this fungal disease is endemic. About $80 \%$ of the patients acquire the disease in Brazil and most of the remaining ones acquire it in other South American countries, mainly Colombia, Venezuela, Argentina, and Ecuador. A total of 168 deaths per year due to paracoccidioidomycosis were recorded in Brazil from 1996 to 2006 [36]. By assuming that the lethality rate of this fungal disease is 3\% to $5 \%$, the number of cases of paracoccidioidomycosis in Brazil is estimated to range from 3360 to 5600 per year.

Previous studies have estimated the annual incidence of paracoccidioidomycosis-disease at 0.96 (São Paulo, Brazil), 0.71 (Rio de Janeiro, Brazil), and 0.90 (Santa Maria, Southern Brazil) per 100,000 inhabitants [21,38]. Between 1980 and 1999, the incidence in the Ribeirão Preto region, Southeastern Brazil, ranged from 1.5 to 3.7 cases/100,000 inhabitants/year [6]. In Colombia, the cases detected between 1970 and 1999 permitted researchers to estimate the incidence of the mycosis between 0.5 and 2.2/100,000 inhabitants/year, with the six municipalities with the highest incidence having rates 
of 0.8 to 3.1/100,000 inhabitants/year [29]. These data led to an estimated occurrence of one to four cases $/ 100,000$ inhabitants per year in geographic areas with stabilized endemicity. In contrast, in a hyperendemic area more recently installed in the state of Rondônia, West Amazon Region, the mean incidence reached 9.4/100,000 inhabitants/year and some municipalities in the Southeastern part of this state had an incidence close to 40 cases/100,000 inhabitants/year [14].

Table 1. Paracoccidioidomycosis endemy dimension in Brazil and other Latin America countries: reported cases number, hospitalization, and mortality rate.

\begin{tabular}{|c|c|c|c|c|c|}
\hline $\begin{array}{c}\text { Country/Geographic } \\
\text { Area }\end{array}$ & $\begin{array}{c}\text { Mortality Rate } \\
{[36]^{\text {a }}}\end{array}$ & $\begin{array}{l}\text { Hospitalization } \\
\text { Rate [37] }^{\mathbf{b}}\end{array}$ & $\begin{array}{c}\text { Reported } \\
\text { Cases (No.) }\end{array}$ & $\begin{array}{c}\text { Annual Mean } \\
\text { Number of Cases }\end{array}$ & $\begin{array}{l}\text { Case Series } \\
\text { References }\end{array}$ \\
\hline Brazil & 1.0 & 4.3 & 12,508 & & \\
\hline North* & 1.8 & 6.1 & 2375 & 159.9 & [12-14] \\
\hline Northeast & 0.2 & 1.6 & 278 & 21.6 & [15] \\
\hline Southeast & 1.0 & 5.7 & 6784 & 207.8 & {$[11,16-20]$} \\
\hline South & 1.5 & 2.4 & 2169 & 140.6 & {$[21-24]$} \\
\hline Midwest & 2.1 & 8.3 & 902 & 49.2 & [25-27] \\
\hline Argentina & & & 110 & 110.0 & [28] \\
\hline Colombia & & & 940 & 32.4 & [29] \\
\hline Venezuela & & & 674 & 25.9 & [30] \\
\hline Ecuador & & & 333 & 15.1 & [31] \\
\hline Paraguay & & & 50 & 5.0 & [32] \\
\hline Peru & & & 111 & 3.3 & [33] \\
\hline Mexico & & & 93 & 3.1 & [34] \\
\hline Uruguay & & & 48 & 1.1 & [35] \\
\hline
\end{tabular}

${ }^{a}$ Mortality rate/1,000,000 inhabitants/year (2002-2004); ${ }^{b}$ Hospitalization rate/100,000 inhabitants/year (1998-2006); ' Sum of the mean number of cases per year in the major series of cases in the same geographical area (1930-2012). * Fonts in italic indicate Brazilian geographical regions.

The deaths due to paracoccidioidomycosis are caused by extremely disseminated lesions, respiratory insufficiency, adrenal insufficiency, and several other complications, and may occur a long time after antifungal treatment. In two case series from different endemic Brazilian areas, lethality reached $6.1 \%$ and $7.6 \%$, respectively [14,39]. However, when assessed at the end of treatment in patients who did not require hospitalization, lethality was zero [40]. A total of 1853 deaths due to paracoccidioidomycosis were recorded in Brazil between 1986 and 2006, representing 51\% of the total number of deaths due to fungal infections [36]. During the period from 1980 to 1995, the mean annual mortality rate per million inhabitants ranged from 0.20 (Northeastern region) to 2.59 (Southern Brazil), and from 2002 to 2004 it ranged from 0.20 (Northeast) to 2.10 (Center-West) [36,41]. The mortality rate is decreasing in the Southern and Southeastern regions of Brazil, while it is increasing in the Northern region, where the states of Rondônia and Acre had rates of 8.2 and 5.6/1,000,000 inhabitants, respectively, in 2002-2004 [36]. Analysis of the data for the five major regions of Brazil reveals that the Brazilian Center-West and North regions simultaneously have the highest rates of hospitalization and mortality (Table 1), suggesting that the western side of Brazil is currently an important endemic area of paracoccidioidomycosis.

\section{Predisposing and Modulating Factors}

The progression from infection to disease due to Paracoccidioides spp. depends on the type of immunological response of the host, but is also influenced or modulated by his genetic background, demographic characteristics, and life conditions and style.

\subsection{Gender}

At prepubertal age, paracoccidioidomycosis equally affects both genders, but after puberty about $75 \%$ to $95 \%$ of the patients are men [17]. Although women are infected with Paracoccidioides spp. as much as men, they are less likely to develop paracoccidioidomycosis apparently because their circulating estrogens inhibit the transformation of the aspirated conidia into yeast cells and also 
modulate the cell immune response against the fungus [42]. The greater proportion of men involved in agricultural activities in endemic areas is an additional factor explaining the predominance of males in case series of this fungal disease. Paradoxically, women of fertile age who progress to paracoccidioidomycosis-disease tend to have more disseminated fungal lesions and clinical signs and symptoms corresponding to the acute/subacute form when compared to men [11]. This fact may be attributed in part to the hormonal and immunity changes that occur during pregnancy, which has been associated with the onset or reactivation of paracoccidioidomycosis [43].

\subsection{Age}

The disease caused by Paracoccidioides spp. has been observed over a wide age range, from two-year-old children to the elderly, although most patients are 30 to 60 years old $[15,20]$. For reasons that are still unknown, but that may possibly be related to immunological-hormonal interactions, the clinical manifestations of paracoccidioidomycosis are strongly associated with the age range of the patient. Children of both sexes exclusively have the acute/subacute form of the mycosis, which also predominates among young adults up to 30 years of age. Starting from the third decade of life, the chronic form of the mycosis is more prevalent [6].

\subsection{Ethnicity}

Racial predisposition to the development of paracoccidioidomycosis has not been detected. However, an analysis of the mycosis in a miscegenated population of Southern Brazil has revealed that blacks and mulattoes more frequently show more disseminated lesions of the acute/subacute form than white patients [11]. The association of the clinical signs and symptoms of the mycosis with ethnicity may be due to the variation of genetic constitution and possibly to differences in living conditions.

\subsection{Genetic Variability}

Comparison of the histocompatibility system of patients with paracoccidioidomycosis to that of healthy subjects has shown that the former have a higher proportion of HLA-A9 and HLA-B13 antigens and the $\mathrm{C}_{4} \mathrm{~B}^{*}-\mathrm{Q} 0$ antigen of the class III major histocompatibility complex was associated with the chronic form of the mycosis [44]. Evaluation of single nucleotide polymorphisms of the genes coding for cytokines has revealed a higher frequency of the IL12RB1 641AA genotype in men with the chronic multifocal form of this fungal disease [45]. These studies suggest that the variation of the genetic background of individuals and of populations living in different endemic areas may be related both to progression of the infection to paracoccidioidomycosis-disease and to its clinical expression.

\subsection{Exposure in Rural Areas}

In case series from different endemic countries, the great majority of patients reported current or past contact with the rural environment due to their profession, residence, or both [25,31]. Exposure at the periphery of cities where the urban and rural zones overlap has also been reported by the patients. Paracoccidioidomycosis is an occupational disease of farmers and of other professionals who are exposed to aerosol containing soil particles. Working with coffee and tobacco crops has been associated with an increased risk to acquire infection and disease due to Paracoccidioides spp. [6,46].

\subsection{Smoking, Alcohol Drinking, and Life Style}

Smoking and the pulmonary changes caused by this habit are strongly associated with later lung involvement by Paracoccidioides spp. In the chronic form of the mycosis, $90 \%$ of the patients are smokers and their risk to develop this disease is 14 times higher among smokers than nonsmokers [23,47]. The intake of distilled alcoholic drinks with mean alcohol quantities exceeding $50 \mathrm{~g}$ per day also favors the onset of paracoccidioidomycosis [47]. It is presumed that a low socioeconomic level, living at the periphery of the urban region, and malnutrition may also facilitate the development of the mycosis. 


\section{Relationship with Cancer, AIDS, and Chronic Infections}

The factors predisposing to paracoccidioidomycosis apparently favor the onset of other diseases in the same patient. Neoplasias, tuberculosis, Chagas disease, leishmaniasis, leprosy, and strongyloidiasis may be more frequent in cases of paracoccidioidomycosis, occurring before, after, or simultaneously with this mycosis [6]. The disease is more commonly associated with tuberculosis which affects up to $15 \%$ to $20 \%$ of the patients [48]. Neoplasias, usually of the carcinoma type, is involved in $0.16 \%$ to $14.1 \%$ of paracoccidioidomycosis cases, arising at varying times, particularly after antifungal treatment of patients with the chronic form of the disease [23,49].

Opportunistic disease due to Paracoccidioides spp. was observed in a few dozen cases in which paracoccidioidomycosis arose concomitantly with or after the diagnosis of hematological or solid organ neoplasias $[23,49]$. This mycosis has been observed in immunosuppressed patients after renal transplantation [50], or in patients with immunological failure due to genetic changes [51]. In endemic areas of Brazil, about $1.5 \%$ of AIDS patients have opportunistic paracoccidioidomycosis, usually with disseminated lesions [52,53], and this mycosis was related to $1.4 \%$ of deaths in AIDS cases [36]. HIV coinfection has been detected in about $5 \%$ of patients with paracoccidioidomycosis [52], but its prevalence is currently decreasing due to the ample and early use of antiretroviral therapy.

\section{Paracoccidioidomycosis-Infection}

Attempts to isolate Paracoccidioides spp. from nature are usually fruitless, a fact that has led to other methods for the assessment of the territorial extension occupied by this microorganism and of the factors related to the infection that precedes paracoccidioidomycosis. This infection is commonly asymptomatic, non-progressive, and has been recognized on the basis of a few case reports and of the investigation of delayed hypersensitivity and of anti-Paracoccidioides spp. antibodies in healthy human populations and in animals.

The clinical manifestations, rarely observed during the early weeks after exposure to Paracoccidioides spp., correspond to the formation of the primary fungal complex and consist of fever, respiratory symptoms, and chest $\mathrm{X}$-rays revealing focal pulmonary lesions and lymphadenomegaly in the pulmonary hilum. These manifestations, particularly the radiographic alterations, can be different from those observed in paracoccidioidomycosis-disease and are self-limited, a fact that hampers the recognition of the Paracoccidioides spp. infection [10]. A few cases progress to the acute/subacute form of paracoccidioidomycosis-disease [54]. Further evidence of asymptomatic or oligosymptomatic infection with Paracoccidioides spp. is observed in some patients with fibrotic pulmonary nodules identified as paracoccidioidomas [55].

The detection of paracoccidioidomycosis infection in healthy individuals is usually based on intradermal application of paracoccidioidin, glycoprotein gp43, and other fungal antigens, and on the measurement of skin reactivity after 24 to $48 \mathrm{~h}$. The results of numerous studies have been reported in two reviews [56,57]. The rates of infection are not directly comparable because of the methodological differences between studies, mainly concerning the use of different antigens. Another limitation is the possibility of cross-reaction with Histoplasma capsulatum antigens [58]. Surveys using intradermal reaction to Paracoccidioides spp. antigens have shown similar rates of infection with this fungus among men and women $[57,59]$. Children in the first decade of life may be positive to the test, but the rate of infection usually increases with age, reaching maximum values after 30 years of age $[59,60]$. Infection with Paracoccidioides spp. has been associated with residence and professional occupation in the rural area and may be favored by contact with coffee cultures, armadillos, and bats $[7,46,61]$.

Figure 1 shows the median rates of paracoccidioidomycosis-infection exclusively obtained in studies of general populations in various Latin-American countries [7,31,38,56,57,59-63]. Individuals reacting to Paracoccidioides spp. were detected in all regions investigated, suggesting that significant parcels of the populations between Northern Argentina and Panama had been infected with this microorganism. More recent studies have detected rates of infection ranging from $4 \%$ to $47 \%$ in Brazil, Argentina, and Venezuela [59,60,62], values comparable to those of surveys held during the last century. 
In Brazil, anti-Paracoccidioides spp. antibodies have been detected in $27 \%$ of blood donors in the state of Paraná and in 5\% of Indians in the state of Minas Gerais [64,65]. These studies suggest previous asymptomatic infection with this fungus, but may also be limited by possible cross-reactivity with other agents of fungal infection.

Intradermal and serological tests conducted on domestic and free or captive wild animals have revealed that various mammals and birds may be infected with Paracoccidioides spp. [66-68]. It was observed that the rate of infection is higher in dogs from the rural area than in dogs from the urban zone and higher in rabbits raised free than in caged animals $[66,69]$. Part of the animals reacting to the tests was sacrificed and Paracoccidioides spp. was not detected in their viscera, suggesting effective control of the fungal infection [69]. On the other hand, there are reports of paracoccidioidomycosis-disease among domestic dogs living in the Brazilian Southeast and South [70,71]. With the exception of armadillos [8,9], this fungal disease was rarely observed in the other wild animals: a squirrel monkey [72], and a two-toed sloth [73] (Figure 1).

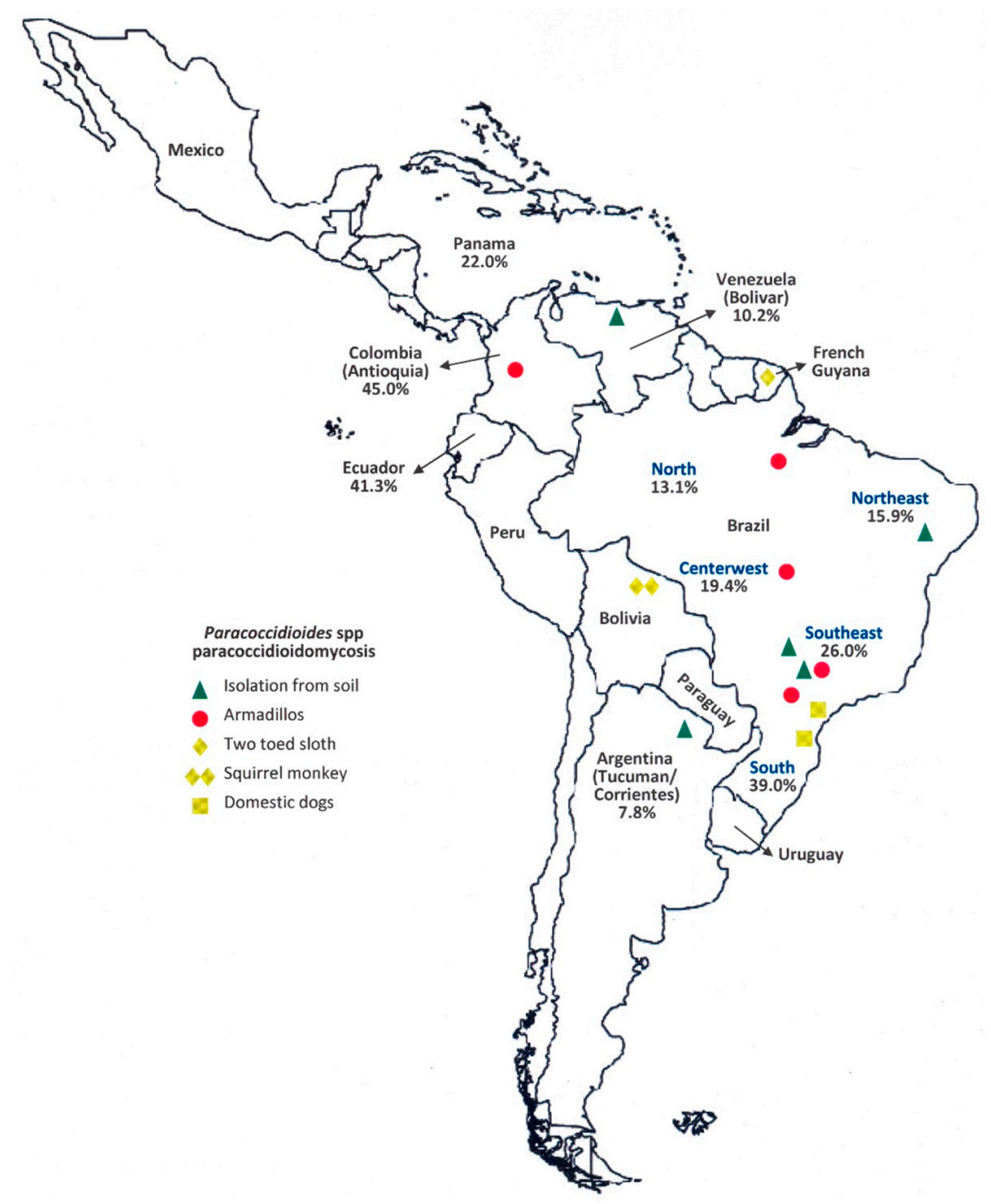

Figure 1. Rate of the Paracoccidioides spp. infection determined by intradermal test in general populations according to geographic area $[7,31,38,56,57,59-63]$. Comparatively, the marks show the places where this fungus was isolated form soil [4] or where captured animals has paracoccidioidomycosis: armadillos [8,9], two-toed sloth [73], squirrel monkey [72], and domestic dogs [70,71]. 


\section{Consolidated Endemic Areas and Expansion of the Endemy}

Autochthonous cases of paracoccidioidomycosis occur only in Latin America from Southern Mexico to Northern Argentina. Coccidioidomycosis and histoplasmosis are more prevalent in Mexico and Central America, where the number of cases of disease due to Paracoccidioides spp. is relatively small. In South America, the endemic areas of histoplasmosis and paracoccidioidomycosis are approximately superimposable, but the disease caused by Paracoccidioides spp. is more prevalent [74].

About 60 cases of paracoccidioidomycosis have occurred in European countries, the United States, Canada, Japan, Africa, and the Middle East [75-77]. However, the patients had visited or previously resided in South American countries and had presented paracoccidioidomycosis immediately or years after returning to their own country. This leads us to assume that Paracoccidioides spp. infection had occurred in South America.

Figure 2 shows the Latin American territories according to the degree of endemicity, as well as the area of expansion of paracoccidioidomycosis. Regions of high endemicity have been recognized since the 1950s in Brazil (Southeast, South, Center-West) [1,18], Colombia (Andes region) [5], and Venezuela (State of Bolivar and North region) [30]. Argentina (North) [28,38], Ecuador (Cuenca River valley) [31], and Paraguay (Oriental side) [32] have areas of moderate to high endemicity. Bolivia, Peru, and Uruguay have autochthonous cases, but the few data available do not permit a precise assessment of the endemic situation of paracoccidioidomycosis [33,35,38]. Southern Mexico, from the Gulf of Mexico to the Pacific Coast, is a territory of low endemicity, as is also the case for Central American countries [34].

Cases of acquired paracoccidioidomycosis currently exist in all major regions of Brazil, except the interior of the Northeast, where the climate is semi-arid. Because of its wide territorial extension and variety of biomes, together with human migration in the search for unexploited areas and agricultural frontiers, Brazil has experienced changes in the epidemiology of paracoccidioidomycosis over time (Figure 2). With a large number of new cases occurring each year, Southeastern Brazil was the first endemic area to be recognized. This was probably due to the extensive use of the rural environment for agriculture and animal husbandry, which exposed many workers to the risk of infection with Paracoccidioides spp. During the first half of the 20th century, coffee plantations occupied large parts of the Southeast, requiring the recruitment of workers from other countries. Many immigrants acquired paracoccidioidomycosis when working at coffee plantations and residing in the rural zone of the state of São Paulo. In a series of 1506 cases completed in 1955, 40\% of the patients were immigrants, most of them from Japan and from European countries [18].

As a consequence of a governmental policy that promoted the occupation and colonization of frontier lands and of the Amazon Region and favored by the construction of highways, a movement of internal migration towards the Center-West and North occurred in Brazil during the second half of the 20th century for the establishment of agriculture and animal husbandry. This was probably the reason for the increased endemicity of paracoccidioidomycosis along the border of the Eastern Amazon Region (states of Tocantins, Pará and Maranhão) [15]. The same phenomenon of population migration and agricultural expansion occurred in the westernmost part of the Brazilian Amazon Region, leading to the onset of a hyperendemic area of paracoccidioidomycosis centered in the state of Rondônia and recognized since the 1990s [14]. In this region, the prevalence of malaria was similarly increased by the immigration [78]. Data regarding mortality and hospitalization due to paracoccidioidomycosis suggest that the southern portion of the Brazilian Amazon Region, extending to the frontier with Bolivia, tends to experience increased endemicity of the mycosis [36,37]. This region is currently undergoing a transformation similar to that of the regions mentioned earlier, involving increased population density, deforestation, and soil movement (Figure 2). Thus, the endemic area is expanding from the South and Southeast regions to the Center-West and North of Brazil. 


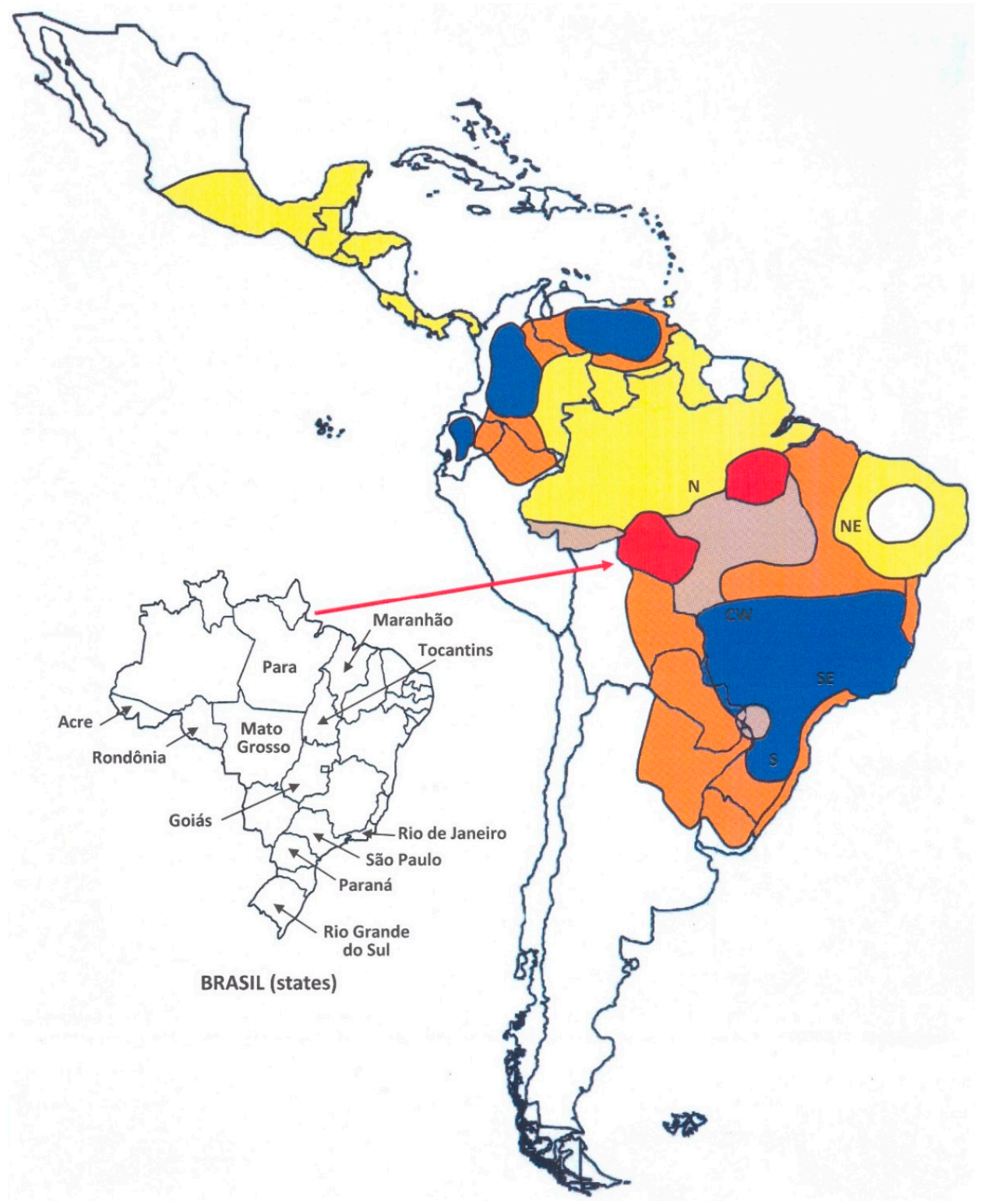

Figure 2. Geographic areas of paracoccidioidomycosis endemicity in Latin America: First recognized areas of high endemicity; $(\nabla)$ high endemicity observed since the last decades of the 20th century; $(\diamond)$ area with some recent evidence of increasing endemicity; $(\checkmark)$ areas of moderate endemicity; $(\quad)$ low endemicity; $(\diamond)$ no areas or rare cases of paracoccidioidomycosis reported in these countries or regions.

\section{Additional Causes of Epidemiological Modification}

In addition to human migration and to the expansion of agricultural frontiers, there is evidence that climate and environmental changes and modifications in agricultural and social practices also have an impact on the occurrence of infection and disease induced by Paracoccidioides spp. An increased incidence of cases of acute/subacute paracoccidioidomycosis has been detected within one to two years after the observance of climate changes causing increased soil and air humidity [16]. The construction of major works involves soil digging, a flow of people, and a permanent environmental impact. An increase in Paracoccidioides spp. infection in the population of Northeastern Argentina was associated with the construction of the Yacyreta hydroelectric plant [63]. The construction of the Jirau and Santo Antônio hydroelectric plants in the Rio Madeira river attracted tens of thousands of 
people to the state of Rondônia and may have contributed to the increased number of cases of infection by this pathogen in the Brazilian western Amazon Region. Foz do Iguaçu, in Southern Brazil, showed a high prevalence of paracoccidioidomycosis in the past decade, perhaps related to the changes brought by the neighboring Itaipu hydroelectric plant and its respective artificial lake [22]. This suggests that the endemicity of paracoccidioidomycosis is increasing in this region, which may possibly include adjacent areas of Paraguay and Argentina (Figure 2) as well.

Changes in agricultural practices in stabilized areas of the endemy have generated the expectation of a long-term reduction of the incidence of paracoccidioidomycosis. The agricultural crops are being progressively mechanized, reducing worker exposure to Paracoccidioides spp. both because of the reduced number of persons involved and due to the lower risk compared to manual work. The extensive coffee plantations in the Brazilian Southeast have been replaced with sugar cane over the last three decades. The manual collection and drying of coffee grains implies a higher risk of aspiration of Paracoccidioides spp. conidia than the cutting of sugar cane, whose plantations undergo previous burning of the leaves which generates enough heat to destroy the microorganisms of the superficial layer of the soil [79]. Since most cases of paracoccidioidomycosis involve a long period of incubation, there is still no evidence of the reduction of the prevalence of the mycosis in areas where agricultural practices are changing.

In addition to the migration of a large portion of the rural population to the cities, child labor has been prohibited in Brazil since the 1990s. The reduced exposure of young people to Paracoccidioides spp. may be related to the progressive reduction of the incidence of acute/subacute paracoccidioidomycosis in case series of the Brazilian Center-West [27]. However, recent cases have been observed in children and young people who supposedly acquired the mycosis in the periphery of cities [80].

Apparently Paracoccidioides spp. grows in many territories and biomes of Latin America, and South America in particular. The fungal infection is closely related to exposure to the rural environment and to soil and vegetable crop manipulation. The existence of unexplored territories, such as those in the Amazon region shared by various South American countries, and human migration patterns following efforts to occupy uninhabited land with agriculture and animal husbandry leads to the prediction of a continued expansion of the endemic area of paracoccidioidomycosis, as already observed in the Brazilian North and Center-West. On the other hand, social and agricultural changes may lead to a reduced incidence of the mycosis in the future. The development of the disease and the type of clinical form manifested in infected people depends on the genetic background, demography, living conditions, and eventual immunosuppression of the host. New endemic areas usually have deficiencies in the structure of medical care, causing a greater social impact of paracoccidioidomycosis, which is a chronic disease requiring protracted treatment that can cause sequelae, disability, and death.

Acknowledgments: Alex Adriano da Silva prepared the maps.

Conflicts of Interest: The author declares no conflict of interest.

\section{References}

1. Lacaz, C.S. Historical Evolution of the knowledge on paracoccidioidomycosis and its etiologic agent, Paracoccidioides brasiliensis. In Paracoccidioidomycosis, 1st ed.; Franco, M., da Lacaz, C.S., Restrepo-Moreno, A., Del Negro, G., Eds.; CRC Press: Boca Raton, FL, USA, 1994; pp. 1-11.

2. Teixeira, M.M.; Theodoro, R.C.; Nino-Vega, G.; Bagagli, E.; Felipe, M.S. Paracoccidioides species complex: Ecology, phylogeny sexual reproduction and virulence. PLoS Pathog. 2014, 10, e1004397. [CrossRef] [PubMed]

3. Arantes, T.D.; Theodoro, R.C.; de Melo Teixeira, M.; de Moraes Gimenes Bosco, S.; Bagagli, E. Environmental mapping of Paracoccidioides spp. in Brazil reveals new clues into genetic diversity, biogeography and wild host association. PLoS Negl. Trop. Dis. 2016, 10, e0004606. [CrossRef] [PubMed]

4. Franco, M.; Bagagli, E.; Scapolio, S.; da Silva Lacaz, C. A critical analysis of isolation of Paracoccidioides brasiliensis from soil. Med. Mycol. 2000, 38, 185-191. [CrossRef] [PubMed] 
5. Restrepo, A.; McEwen, J.G.; Castañeda, E. The habitat of Paracoccidioides brasiliensis: How far from solving the riddle? Med. Mycol. 2001, 39, 233-241. [CrossRef] [PubMed]

6. Bellíssimo-Rodrigues, F.; Machado, A.A.; Martinez, R. Paracoccidioidomycosis epidemiological features of a 1000-cases series from a hyperendemic area on the Southeast of Brazil. Am. J. Trop. Med. Hyg. 2011, 85, 546-550. [CrossRef] [PubMed]

7. Cadavid, D.; Restrepo, A. Factors associated with Paracoccidioides brasiliensis infection among permanent residents of three endemic areas in Colombia. Epidemiol. Infect. 1993, 111, 121-133. [CrossRef] [PubMed]

8. Bagagli, E.; Franco, M.; Bosco Sde, M.; Hebeler-Barbosa, F.; Trinca, L.A.; Montenegro, M.R. High frequency of Paracoccidioides brasiliensis infection in armadillos: An ecological study. Med. Mycol. 2003, 41, 217-223. [CrossRef] [PubMed]

9. Corredor, G.G.; Castaño, J.H.; Peralta, L.A.; Diéz, S.; Arango, M.; McEwen, J.; Restrepo, A. Isolation of Paracoccidioides brasiliensis from nine-banded armadillo Dasypus novemcinctus, in a endemic area for paracoccidioidomycosis in Colombia. Rev. Iberoam. Micol. 1999, 16, 216-220. [PubMed]

10. Buccheri, R.; Khouri, Z.; Barata, L.C.; Benard, G. Incubation period and early natural history events of the acute form of paracoccidioidomycosis: Lessons from patients with single Paracoccidioides spp. exposure. Mycopathologia 2016, 181, 435-439. [CrossRef] [PubMed]

11. Bellíssimo-Rodrigues, F.; Bollela, V.R.; da Fonseca, B.A.L.; Martinez, R. Endemic paracoccidioidomycosis: Relationship between clinical presentation and patients' demographic features. Med. Mycol. 2013, 51, 313-318. [CrossRef] [PubMed]

12. Talhari, S.; Cunha, M.G.; Sehettini, A.P.; Talhari, A.C. Deep mycoses in Amazon region. Int. J. Dermatol. 1988, 27, 481-484. [CrossRef] [PubMed]

13. Fonseca, E.R.; Pardal, P.P.; Severo, L.C. Paracoccidioidomicose em crianças em Belém do Pará. Rev. Soc. Bras. Med. Trop. 1999, 32, 31-33. [CrossRef] [PubMed]

14. Vieira, G.D.; Alves, T.C.; Lima, S.M.D.; Souza, C.M. Paracoccidioidomycosis in a western Brazilian Amazon State: Clinical-epidemiologic profile and spatial distribution of the disease. Rev. Soc. Bras. Med. Trop. 2014, 47, 63-68. [CrossRef] [PubMed]

15. Matos, W.B.; Dos Santos, G.M.C.; Silva, V.E.B.; Rosário Gonçalves, E.G.; Silva, A.R. Paracoccidioidomycosis in the state of Maranhão, Brazil: Geographic and clinical aspects. Rev. Soc. Bras. Med. Trop. 2012, 45, 385-389. [CrossRef] [PubMed]

16. Barrozo, L.V.; Mendes, R.P.; Marques, S.A.; Benard, G.; Siqueira Silva, M.E.; Bagagli, E. Climate and acute/subacute paracoccidioidomycosis in a hyperendemic area in Brazil. Int. J. Epidemiol. 2009, 38, 1642-1649. [CrossRef] [PubMed]

17. Blotta, M.H.; Mamoni, R.I.; Oliveira, S.J.; Nouer, S.A.; Papaiordanou, P.M.; Goveia, A.; Camargo, Z.P. Endemic regions of paracoccidioidomycosis in Brazil: A clinical and epidemiologic study of 584 cases in the southeast region. Am. J. Trop. Med. Hyg. 1999, 61, 390-394. [PubMed]

18. Lacaz, C.S. South American blastomycosis. An. Fac. Med. Univ. Sao Paulo 1956, 29, 9-120.

19. Neves, F.F.; Gerolin, G.P.; Tavares, M.G.; Castro-Silva, M.H.; Lopes, G.P.; Michelin, M.A.; Silva-Vergara, M.L. Epidemiological and clinical profile of 137 patients with paracoccidioidomycosis in Uberaba, Minas Gerais, Brazil. In Proceedings of the $X$ International Congress on Paracoccidioidomycosis, Medellin, Colombia, 7-10 August 2008; Biomédica: Medellin, Colombia, Volume 28, p. 144.

20. Valle, A.C.F.; Wanke, B.; Fernandes, N.C.; Peixoto, T.C.; Perez, M. Tratamento da paracoccidioidomicose: Estudo retrospectivo de 500 casos. I. Análise clínica, laboratorial e epidemiológica. An. Bras. Dermatol. 1992, $67,251-254$.

21. Londero, A.T.; Ramos, C.D. Paracoccidioidomicose. Estudo clínico e micológico de 260 casos observados no interior do Estado do Rio Grande do Sul. J. Pneumol. 1990, 16, 129-132.

22. Loth, E.A.; Castro, S.V.; Silva, J.R.; Gandra, R.F. Ocurrence of 102 cases of paracoccidioidomycosis in 18 months in the Itaipu Lake region, Western Paraná. Rev. Soc. Bras. Med. Trop. 2011, 44, 636-637. [CrossRef] [PubMed]

23. Rodrigues Gda, S.; Severo, C.B.; Oliveira Fde, M.; Moreira Jda, S.; Prolla, J.C.; Severo, L.C. Association between paracoccidioidomycosis and cancer. J. Bras. Pneumol. 2010, 36, 356-362. [PubMed]

24. de Souza, S.P.; Jorge, V.M.; Xavier, M.O. Paracoccidioidomycosis in southern Rio Grande do Sul: A retrospective study of histopathologically diagnosed cases. Braz. J. Microbiol. 2014, 45, 243-247. [CrossRef] [PubMed] 
25. Andrade, A.L.S.S. Paracoccidioidomicose linfático-abdominal. Contribuição ao seu estudo. Rev. Patol. Trop. 1983, 12, 165-256.

26. Campos, M.V.; Penna, G.O.; Castro, C.N.; Moraes, M.A.; Ferreira, M.S.; Santos, J.B. Paracoccidioidomicose no hospital universitário de Brasília. Rev. Soc. Bras. Med. Trop. 2008, 41, 169-172. [CrossRef] [PubMed]

27. Fabris, L.R.; Andrade, U.V.; Ferreira dos Santos, A.; Marques, A.P.; Oliveira, S.M.; Mendes, R.P.; Paniago, A.M. Decreasing prevalence of the acute/subacute clinical form of paracoccidioidomycosis in Mato Grosso do Sul State, Brazil. Rev. Inst. Med. Trop. Sao Paulo 2014, 56, 121-125. [CrossRef] [PubMed]

28. Davel, C.; Canteros, C.E. Situación de lãs micosis em La República Argentina. Rev. Argent. Microbiol. 2007, 39, 28-33. [PubMed]

29. Calle, D.; Rosero, D.S.; Orozco, L.C.; Camargo, D.; Castañeda, E.; Restrepo, A. Paracoccidioidomycosis in Colombia: An ecological study. Epidemiol. Infect. 2001, 126, 309-315. [CrossRef] [PubMed]

30. Martínez Mendéz, D.; Hernández Valles, R.; Alvarado, P.; Mendoza, M. Las micosis en Venezuela: Casuística de lós grupos de trabajos em micologia (1984-2010). Rev. Iberoam. Micol. 2013, 30, 39-46. [CrossRef] [PubMed]

31. Lazo, R.F.; Fernández, T.; Mera, R. Prevalencia en la paracoccidioidomycosis e histoplasmosis em la cuenca Del Rio Guayas. Rev. Ecuat. Hyg. Med. Trop. 1987, 37, 15-35.

32. Rolón, P.A. Paracoccidioidomycosis: Epidemiologia en la República Del Paraguay, centro Sud América. Mycopathologia 1976, 59, 67-80. [CrossRef] [PubMed]

33. Burstein, Z. Aspectos clínicos de la Blastomicosis sudamericana (Paracoccidioidomicosis) en el Perú. Rev. Peru. Exp. Salud Publica 2002, 19, 43-47.

34. López-Martínez, R.; Hernandez-Hernandez, F.; Mendez-Toiar, L.J.; Manzano-Gayosso, P.; Bonilfaz, A.; Arenas, R.; Padilla-Desgarennes Mdel, C.; Estrada, R.; Chávez, G. Paracoccidioidomycosis in Mexico: Clinical and epidemiological data from 93 new cases (1972-2012). Mycoses 2014, 57, 525-530. [CrossRef] [PubMed]

35. Conti-Diáz, I.A.; Calegari, L.F. Paracoccidioidomycosis en Uruguay: Su estado y problemática actuales. Bol. Oficina Sanit. Panam. 1979, 86, 219-229. [PubMed]

36. Prado, M.; Silva, M.B.; Laurenti, R.; Travassos, L.R.; Taborda, C.P. Mortality due to systemic mycosis as a primary cause of death or in association with AIDS in Brazil: Review from 1996 to 2006. Mem. Inst. Oswaldo Cruz 2009, 104, 513-521. [CrossRef] [PubMed]

37. Coutinho, Z.F.; Wanke, B.; Travassos, C.; Oliveira, R.M.; Xavier, D.R.; Coimbra, C.E., Jr. Hospital morbidity due to paracoccidioidomycosis in Brazil (1998-2006). Trop. Med. Int. Health 2015, 20, 673-680. [CrossRef] [PubMed]

38. Greer, D.L.; Restrepo, A.M. La epidemiologia de la paracoccidioidomycosis. Bol. Oficina Sanit. Panam. 1977, $82,428-445$.

39. Paniago, A.M.M.; Aguiar, J.I.A.; Aguiar, E.S.; da Cunha, R.V.; Pereira, G.R.; Londero, A.T.; Wanke, B. Paracoccidioidomicose: Estudo clínico e epidemiológico de 422 casos observados no Estado de Mato Grosso do Sul. Rev. Soc. Bras. Med. Trop. 2003, 36, 455-459. [CrossRef] [PubMed]

40. Queiroz-Telles, F.; Goldani, L.Z.; Schlamm, H.T.; Goodrich, J.M.; Espinel-Ingroff, A.; Shikanai-Yasuda, M.A. An open label comparative study of oral voriconazole and itraconazole for long-term treatment of paracoccidioidomycosis. Clin. Infect. Dis. 2007, 45, 1462-1469. [CrossRef] [PubMed]

41. Coutinho, Z.F.; da Silva, D.; Lazera, M.; Petri, V.; Oliveira, R.M.; Sabroza, P.C.; Wanke, B. Paracoccidioidomycosis mortality in Brazil (1980-1995). Cad. Saude Publica 2002, 18, 1441-1454. [CrossRef] [PubMed]

42. Shankar, J.; Restrepo, A.; Clemons, K.V.; Stevens, D.A. Hormones and the resistance of women to paracoccidioidomycosis. Clin. Microbiol. Rev. 2011, 24, 296-313. [CrossRef] [PubMed]

43. Loth, E.A.; Cecatto, V.; Biazim, S.K.; Ferreira, J.H.; Danielli, C.; Genske, R.D.; Gandra, R.F.; Franco, M.F. Experimental paracoccidioidomycosis in pregnant rats. Rev. Inst. Med. Trop. Sao Paulo 2015, 57, 515-518. [CrossRef] [PubMed]

44. De Messias, I.J.; Reis, A.; Brenden, M.; Queiroz-Telles, F.; Mauff, G. Association of major histocompatibility complex class III complement components C2, BF, and C4 with Brazilian paracoccidioidomycosis. Complement. Inflamm. 1991, 8, 288-293. [PubMed] 
45. Carvalho, F.M.; Busser, F.D.; Freitas, V.L.; Furucho, C.R.; Sadahiro, A.; Kono, A.S.; Criado, P.R.; Moretti, M.L.; Sato, P.K.; Shikanai-Yasuda, M.A. Polymorphisms on IFNG, IL12B and IL12RB1 genes and paracoccidioidomycosis in the Brazilian population. Infect. Genet. Evol. 2016, 43, 245-251. [CrossRef] [PubMed]

46. Coimbra Junior, C.F.; Wanke, B.; Santos, R.V.; do Valle, A.C.; Costa, R.L.; Zancopé-Oliveira, R.M. Paracoccidioidin and histoplasmin sensitivy in Tupi-Mondé Ameridian populations from Brazilian Amazonia. Ann. Trop. Med. Parasitol. 1994, 88, 197-207. [CrossRef] [PubMed]

47. Dos Santos, W.A.; da Silva, B.M.; Passos, E.D.; Zandonade, E.; Falquete, A. Associação entre tabagismo e paracoccidioidomicose: Um estudo de caso-controle no Estado do Espírito Santo, Brasil. Cad. Saude Publica 2003, 19, 245-253. [CrossRef] [PubMed]

48. Quagliato Junior, R.; Granjeia Tde, A.; Massucia, R.A.; De Capitani, E.M.; Rezende Sde, M.; Balthazar, A.B. Association between paracoccidioidomycosis and tuberculosis: Reality and misdiagnosis. J. Bras. Pneumol. 2007, 33, 295-300. [PubMed]

49. Shikanai-Yasuda, M.A.; Conceição, Y.M.; Kono, A.; Rivitti, E.; Campos, A.F.; Campos, S.V. Neoplasia and paracoccidioidomycosis. Mycopathologia 2008, 165, 303-312. [CrossRef] [PubMed]

50. Pontes, A.M.; Borborema, J.; Correia, C.R.; de Almeida, W.L.; Maciel, R.F. A rare paracoccidioidomycosis diagnosis in a kidney transplant receptor: Case report. Transpl. Proc. 2015, 47, 1048-1050. [CrossRef] [PubMed]

51. Moraes Vasconcelos, D.; Grumach, A.S.; Yamaguti, A.; Andrade, M.F.; Fieschi, C.; de Beaucoudrey, L.; Casanova, J.L.; Duarte, A.J. Paracoccidioides brasiliensis disseminated disease in a patient with inherited deficiency in the beta 1 subunit of the interleukin (IL)-12/IL-23 receptor. Clin. Infect. Dis. 2005, 41, e31-e37. [CrossRef] [PubMed]

52. Morejón, K.M.; Machado, A.A.; Martinez, R. Paracoccidioidomycosis in patients infected with and not infected with human immunodeficiency vírus: A case-control study. Am. J. Trop. Med. Hyg. 2009, 80, 359-366. [PubMed]

53. Paniago, A.M.; de Freitas, A.C.; Aguiar, E.S.; Aguiar, J.I.; da Cunha, R.V.; Castro, A.R.; Wanke, B. Paracoccidioidomycosis in patients with human immunodeficiency virus: Review of 12 cases observed in an endemic region on Brazil. J. Infect. 2005, 51, 248-252. [CrossRef] [PubMed]

54. Martinez, R.; Moya, M.J. Complexo primário da paracoccidioidomicose e hipereosinofilia. J. Bras. Pneumol. 2009, 35, 1259-1262. [CrossRef] [PubMed]

55. Dos Santos, J.W.; Michel, G.T.; Londero, A.T. Paracoccidioidoma: Case report and review. Mycopathologia 1997, 137, 83-85. [CrossRef] [PubMed]

56. Fava, S.; di, C.; Netto, C.F. Epidemiologic surveys of histoplasmin and paracoccidioidin sensitivity in Brazil. Rev. Inst. Med. Trop. Sao Paulo 1998, 40, 155-164. [CrossRef]

57. Pereira, A.J.C.S. Inquérito intradérmico para paracoccidioidomicose em Goiânia. Rev. Patol. Trop. 1988, 17, 157-186.

58. Kalmar, E.M.; Alencar, F.E.; Alves, F.P.; Pang, L.W.; Del Negro, G.M.; Camargo, Z.P.; Shikanai-Yasuda, M.A. Paracoccidioidomycosis: An epidemiologic survey in a pediatric population from the Brazilian Amazon using skin tests. Am. J. Trop. Med. Hyg. 2004, 71, 82-86. [PubMed]

59. Marques, A.P.; Oliveira, S.M.; Rezende, G.R.; Melo, D.A.; Fernandes-Fitts, S.M.; Pontes, E.R.; Bonecini-Almeida Mda, G.; Camargo, Z.P.; Paniago, A.M. Evaluation of Paracoccidioides brasiliensis infection by the gp43 intradermal test in rural settlements in Central-West Brazil. Mycopathologia 2013, 176, 41-47. [CrossRef] [PubMed]

60. Cermeño, J.; Cermeño, J.; Godoy, G.; Hernández, I.; Orellán, Y.; Blanco, Y.; Penna, S.; García, L.; Mender, T.; Gonsálvez, M.; et al. Epidemiological study of paracoccidioidomycosis and histoplasmosis in a suburb of San Felix city, Bolivar State, Venezuela. Investg. Clin. 2009, 50, 213-220.

61. De Martin, M.C.; Suaréz, M. Infection caused by Paracoccidioides brasiliensis in people living in Cocle and Veraguas, Republic of Panama. Rev. Med. Panama 1989, 14, 112-115. [PubMed]

62. Van Gelderen de Komaid, A.; Durán, E.; Borges de Kestelman, I. Histoplasmosis and paracoccidioidomycosis in northwestern Argentina. III. Epidemiological survey in Vipos, La Toma, and Choromoro-Trancas, Tucumán, Argentina. Eur. J. Epidemiol. 1999, 15, 383-388. [PubMed] 
63. Mangiaterra, M.L.; Giusiano, G.E.; Alonso, J.M.; Gorodner, J.O. Paracoccidioidomycosis infection in a subtropical region with important environmental changes. Bull. Soc. Pathol. Exot. 1999, 92, 173-176. [PubMed]

64. Maluf, M.L.; Pereira, S.R.; Takahachi, G.; Svidzinski, T.I. Prevalência da paracoccidioidomicose-infecção determinada através de teste sorológico em doadores de sangue na região noroeste do Paraná, Brasil. Rev. Soc. Bras. Med. Trop. 2003, 36, 11-16. [CrossRef] [PubMed]

65. Martinez, R.; Vitali, L.H.; Henriques, J.H.; Machado, A.A.; Albernaz, A.; Lima, A.A. Inquérito soroepidemiológico para infecções por fungos causadores de micoses sistêmicas na Reserva Indígena Xacriabá, Estado de Minas Gerais. Rev. Soc. Bras. Med. Trop. 2002, 35, 347-350. [CrossRef] [PubMed]

66. Belitardo, D.R.; Calefi, A.S.; Sbeghen, M.R.; de Oliveira, G.G.; Watanabe, M.A.; de Camargo, Z.P. Paracoccidioides brasiliensis infection in domestic rabbits (Oryctolagus cuniculus). Mycoses 2014, 57, 222-227. [CrossRef] [PubMed]

67. Albano, A.P.; Klafke, G.B.; Brandolt, T.M.; da Hora, V.P.; Nogueira, C.E.; Xavier, M.O.; Meireles, M.C. Seroepidemiology of Paracoccidioides brasiliensis infection in horses from Rio Grande do Sul, Brazil. Braz. J. Microbiol. 2015, 46, 513-517. [CrossRef] [PubMed]

68. Sbeghen, M.R.; Zanata, T.B.; Macagnan, R.; de Abreu, K.C.; da Cunha, W.L.; Watanabe, M.A.; de Camargo, Z.P.; Ono, M.A. Paracoccidioides brasiliensis infection in small wild mamals. Mycopathologia 2015, 180, 435-470. [CrossRef] [PubMed]

69. Fontana, F.F.; dos Santos, S.T.; Esteves, F.M.; Rocha, A.; Fernandes, G.F.; do Amaral, C.C.; Domingues, M.A.; de Camargo, Z.P.; Silva-Vergara, M.L. Seroepidemiological survey of paracoccidioidomycosis infection among urban and rural dogs from Uberaba, Minas Gerais, Brazil. Mycopathologia 2010, 169, 159-165. [CrossRef] [PubMed]

70. Ricci, G.; Motta, F.T.; Wakamatsu, A.; Serafim, R.C.; Borra, R.C.; Franco, M. Canine paracoccidioidomycosis. Med. Mycol. 2004, 42, 379-383. [CrossRef] [PubMed]

71. de Farias, M.R.; Condas, L.A.Z.; Ribeiro, M.G.; Bosco Sde, M.; Muro, M.D.; Werner, J.; Theodoro, R.C.; Bagagli, E.; Marques, S.A.; Franco, M. Paracoccidioidomycosis in a dog: Case report of generalized lymphadenomegaly. Mycopathologia 2011, 172, 147-152. [CrossRef] [PubMed]

72. Johnson, W.D.; Lange, C.M. Paracoccidoidomycosis (South American Blastomycosis) in a squirrel monkey (Saimiri sciureus). Vet. Pathol. 1977, 14, 368-371. [PubMed]

73. Trejo-Cháves, A.; Ramírez-Romero, R.; Ancer-Rodríguez, J.; Nevárez-Garza, A.M.; Rodríguez-Trovar, L.E. Disseminated paracoccidioidomycosis in a Souther two-toed sloth (Choloepus didactylus). J. Comp. Pathol. 2011, 144, 231-234. [CrossRef] [PubMed]

74. Faiolla, R.C.; Coelho, M.C.; Santana, R.; de, C.; Martinez, R. Histoplasmosis in immunocompetent individuals living in an endemic area in the Brazilian Southeast. Rev. Soc. Bras. Med. Trop. 2013, 46, 461-465. [CrossRef] [PubMed]

75. Ajello, L.; Polonelli, L. Imported paracoccidioidomycosis: A public health problem in non-endemic areas. Eur. J. Epidemiol. 1985, 1, 160-165. [CrossRef] [PubMed]

76. Buitrago, M.J.; Cuenca-Estrella, M. Current epidemiology and laboratory diagnosis of endemic mycosis in Spain. Enferm. Infecc. Microbiol. Clin. 2012, 30, 407-413. [CrossRef] [PubMed]

77. Kamei, K.; Sano, A.; Kikuchi, K.; Makimura, K.; Niimi, M.; Suzuki, K.; Uehara, Y.; Okabe, N.; Nishimura, K.; Miyaji, M. The trends of imported mycosis in Japan. J. Infect. Chemother. 2003, 9, 16-20. [CrossRef] [PubMed]

78. McGreevy, P.B.; Dietze, R.; Prata, A.; Hembree, S.C. Effects of imigration on the prevalence of malaria in rural areas of the Amazon basin of Brazil. Mem. Inst. Oswaldo Cruz 1989, 84, 485-491. [CrossRef] [PubMed]

79. Valera, C.A.; Valle Júnior, R.F.; Varandas, S.G.; Sanches Fernandes, L.F.; Pacheco, F.A. The role of environmental land use conflicts in soil fertility: A study in the Uberaba River basin, Brazil. Sci. Total Environ. 2016, 562, 463-473. [CrossRef] [PubMed]

80. Restrepo, M.A. The natural habitat of the fungus Paracoccidioides brasiliensis, how to draw the limit between the rural and the urban environment? Biomedica 2014, 34, 5-6. [CrossRef] [PubMed]

(c) 2017 by the author; licensee MDPI, Basel, Switzerland. This article is an open access article distributed under the terms and conditions of the Creative Commons Attribution (CC-BY) license (http:/ / creativecommons.org/licenses/by/4.0/). 